\title{
Use and protection of water bodies: corruption cases
}

\author{
D.O. Sivakov ${ }^{1}$, V.V. Sevalnev ${ }^{1}$, Y.V. Truntsevsky ${ }^{1 *}$ \\ ${ }^{1}$ Institute of Legislation and Comparative Law under the Government of the Russian Federation, \\ Cheremushkinskaya str., 34, Moscow, 117218, Russia
}

\begin{abstract}
Corruption practicies that occure in the field of water bodies utilisation and protection in Russia increase ecological threats and undermine the system of legal regulation of relations on use and protection of the Water Fund. In the proposed article the authors conduct a critical analysis of the legal regulation for water relations (federal laws, regulatory legal acts, judicial practice) for the purpose of identifying the corruption risks and recorded corruption practicies in order to minimize and eliminate them. Basing on the judicial practice and scientific research results, the authors reveal several "painful points" of water legislation in Russia with respect to corruption risks and activities. The authors propose to fill the gaps in the existing law, which will effectively ensure the prevention and suppression of corruption in the utilization and protection of water bodies. The article applies methods of systemic analysis and modeling, and also uses universal scientific methods of induction and deduction, as well as abstraction. The thematic sections addressed by the study include: corruption risks and practicies at the present stage of the Water Act development; small water bodies and corrupt activities; Underground water objects and corruption risks; Monopoly and corruption risks in the field of water relations as well as Possibilities of public control in connection with corruption risks and practicies in Russia.
\end{abstract}

\section{Introduction}

Corruption risks and activities in the field of water relations mostly happen due to gaps and contradictions in the water legislation. It should be noted alone that the problem of addressing corruption does not exist in isolation from other tasks of legal regulations for the vast water fund of Russia development and use. Corruption appears as a significant obstacle for ensuring sustainable water use and it considerably complicates the protection of water bodies. In this sense, it enhances environmental challenges associated with wasteful utilization of water resources, such as a large percentage of water losses and a decrease in real sewage treatment below the established rates. At the same time, a fight against corruption does not abolish the task of attracting and protecting investments in the water management and water transport infrastructure, providing the introduction of resourceefficient technologies.

'Corresponding author: truzev@yandex.ru 
An important task of the study is to review the relations on the subject of water bodies and the entire water fund of Russia use and protection in the light of the anticorruption policy. In Russia, comprehensive legislation on fighting corruption has been formed, regulating, among other things, relations existing in the field of natural resources.

The main Federal Law No. 273-FZ of December 25, 2008 "On Combating Corruption" defines corruption as abuse of power, giving bribes, accepting bribes, abuse of authority, commercial bribery or other unlawful use of an individual official position, contrary to legitimate interests of the society and the state in order to obtain benefits in the form of money, valuables, other property or services of a property nature, as well as other property rights for such individuals or for third parties. For the first time in Russia, a legal definition of corruption was given, which is significant for the further development of the anticorruption legisltion.

The law also defines the concept of combating corruption as the activities of federal government bodies, state authorities of the subjects of the Russian Federation, local government bodies, civil society institutions, organizations and individuals within their powers:

- on the prevention of corruption, including the identification and subsequent elimination of corruption causes (prevention of corruption);

- on detection, prevention, suppression, disclosure and investigation of corruption offenses (combating corruption);

- on minimization and (or) elimination of consequences of corruption offenses.

Presidential Decree No. 460 of April 13, 2010 approved the National Anti-Corruption Strategy. (2)

In this Strategy, the basic principles of combating corruption are as following:

- recognizing corruption as one of the systemic threats to the security of the Russian Federation;

- applying measures to the anti-corruption system, including measures to prevent corruption, to prosecute the perpetrators of corruption crimes, and to minimize and (or) eliminate the consequences of corruption, with the leading role of measures to prevent corruption at the present stage.

The strategy provides appropriate implementation mechanisms. Along with the control in the formation and execution of budgets of all levels, the resolution of personnel issues, the unification of legal acts by their prompt alignment with the requirements of federal laws on anti-corruption issues, the Strategy draws attention to the need to ensure the inevitability of liability for corruption offenses and the objective application of the legislation of the Russian Federation, as well as the need to actively engage political parties, civil groups and other civil society institutions in the anti-corruption work

The anti-corruption strategy is a general policy document, the provisions of which should be sequentially specified taking into account the requirements of the time in the National Anti-Corruption Plan for the relevant period (2), as well as in plans to address corruption of federal state bodies, authorities of the subjects of the Russian Federation and municipalities. The National Anti-Corruption Plan is a document that sets out specific anticorruption measures on an all-Russian scale [1].

\section{Methods}

Corruption risks and manifestations at the present stage of development of water law.

The Water Code of the Russian Federation (hereinafter - VC RF) has been in effect for ten years by now, and it is the "core" of the water legislation of our country. The notion VK RF implies a new stage in the development of the Water Law [2], [3]. In general, this stage of development is characterized by a significant reduction in administrative (permissive) 
means of regulation. The legislator intends to provide the participants of the relations with greater independence, which is expressed in the development of contractual relations. However, this alone fundamentally complicates rather than abolishes corruption risks and practicies.

The Russian Federation's VC was changing every year for ten years in 2006 -2016. In 2017, several projects were developed in order to change the VK RF and other Acts on water use regulations. However, the Russian Water Law provisions remain inadequate, deficient and vague. Meanwhile, flaws in the water legislation have a negative impact on law enforcement practicies: e.g. complicated litigation arises.

Corruptive practicies lead to violation of water use requirements and conditions, undermine the legal regulation of water protection and sanitary zones, especially in those areas that are attractive for investment in construction.

Russian scientists note that the provisions of the water legislation on the general use of water bodies and their shorelines (with a number of exceptions), the free of charge nature of their use for personal and household needs are not always implemented in practice. Due to corruption practicies, officials often do not allocate a shoreline for public use, they also encourage constructions on banks of water bodies right up to the water edge, which in its turn restricts the legitimate access to water for public. At the same time, a disagreement from the public occures (the public representatives gather information on seized water banks) [4].

Undocumented according to the requirements of the law but "missed" by local authorities and officials intake and discharge of water resources from hard-to-reach water bodies by economic agents are potentially dangerous. Unaccounted water intakes, boreholes and hand-dug wells, unauthorized pumping of sewage into the bowels pose a danger as well.

For these reasons, acts of corruption that are being researched, even with plentiful water resources, violate the system of protection of the water fund and the scientifically justified regulation of water use. After all, according to experts, water intake over $15 \%$ of a river flow can lead to a gradual depletion of the watercourse [5].

Quite often, courts find violations in organization of auctions on contracts for water use. Courst also observe violation of some contracts' terms for water use, and also use of water bodies and watercourses by business entities without any water use contracts. There are also many wrongful decisions on granting water objects for use (even in cases when it is made according to the law).

In practice, there are situations when water use agreements, contrary to the requirements of Article 13 of the VK RF, do not provide information about the water body or part thereof, including a description of a location of a shoreline (boundaries of the water body) where water use is intended. This creates certain opportunities for manipulation. In such cases, the courts reasonably consider the contracts in question to be not concluded.

\section{Results}

Small water bodies and corruption activities

Proceeding from the fundamental provisions of Article 8. VK RF, water objects are in the Federal ownership. The exceptions are ponds and watered quarries located within the boundaries of land plots owned by the subject of the Russian Federation, municipalities, individuals, or a legal entity. Such water bodies are respectively owned by the subject of the Russian Federation, municipalities, individuals, legal entity, unless otherwise is established by the Federal laws.

The right of ownership of the Russian Federation and an entity of the Russian Federation, a municipality, an individual, a legal entity to a pond, a watered quarry shall 
terminate simultaneously with the termination of the ownership of the relevant land plot within which such water bodies are located. At the same time, the legislator does not define concepts of ponds and watered quarries, that in practice complicates a definition of water bodies range that can be privately owned. In turn, some definitions of different types of water bodies in GOSTs are not ligally binding and alone can not fill the gap in the legislation shortcomings.

A number of ponds were formed by the support of rivers and creeks. The waterstream ponds formed in this way, although they became a part of the watercourse (rivers or creeks) from the point of view of hydrology, they do not have the same destiny clearly defined by the legislator. In this part of the legislation, both federal and regional, forms of the ownership of waterstream ponds are not either determined or allowed. Gaps in the legislation contribute to the aspirations of a number of individuals and legal entities to purchase the named waterstream bodies into their ownership or to lease these reservoirs along with adjacent land plots [6].

As a rule, the practice of arbitration courts, does not support such claims and it is on the way of securing state ownership of such water bodies. As an example, we should mention the decision of the Arbitration Court of the North Caucasus District from November 30, 2015, case No. A63-6060 / 2014. In this ruling basing on the circumstances of the case, the court made an important conclusion: the location of ponds on the Kamenna Gorka girder watercourse (left tributary of the Tuguluk river) and the Klyuchevka river and their reference to the water area of the above-mentioned surface objects and, accordingly, the presence of a hydraulic link between them indicates belonging of the the mentioned above objects to the federal property, therefore the impossibility of the formation of land plots under them and a restriction in turnover exist.

The above litigation concerns a river pond on and a pond on a temporary watercourse (in the beam), serving as a tributary of the river. Any formation of a stream pond, even on a small river or a creek 1 , does not mean that, with the change in some hydrological conditions (associated with the support of a small dam), the man-made reservoir formed ceases to be part of a permanent or temporary watercourse. For these reasons, this reservoir (pond) cannot be privately owned, if in fact it is a part of a federal watercourse (a river or a creek). The named "if" has a very definite meaning: after all, there are cases when in a few decades (30-40 years) after a backwater and then covering, small watercourses ceased to exist. Nevertheless, this needs to be confirmed through an objective and unbiased examination appointed by the court. The expertise of that kind is of a particular importance providing the obsolescence nature of many data of the state water register.

Another judicial dispute should also be cited. Let's turn to the decision of the Arbitration Court of the Volga-Vyatka District of October 23, 2015 No. F01-3770 / 2015 in case No. A39-4786 / 2014, which contains the following representative facts and circumstances.

The courts established the following: the stream Ivanov Creek that is four kilometers long along the territory of the Chamzi district of the Republic of Mordovia and is located to the south of the district village of Chamzinka, about 1500 meters from the village of Ivanova Polyana; the stream flows into the Malaya Ksha River, which is included in the Water Register of Russia under code 08010500312110000036784 , the pool code is 08.01.05.003. According to the State Water Register of Russia, the Malaya Ksha River belongs to the Upper Volga Basin District, the river sub-basin of the river is Sura. This river flows not only in the Republic of Mordovia, but also in the Penza region and the Chuvash Republic. The mouth is 4.9 kilometers along the left bank of the Great Ksa River. Therefore, the river Malaya Ksha and the creek Ivanov Klyuch are in federal ownership.

Ivanovo-Polyansky pond is a natural stream water body due to its location directly on the creek Ivanov Klyuch - on a stream (on a creek), and has a natural hydraulic connection with other surface water objects - the Malaya Ksha and Volga rivers and was formed as a 
result of the construction of a hydraulic structure, regulating the water regime of the pond.

Since the alienation of the land plot on the basis of the Purchase and Sale agreement No. 87 of September 13, 2013 was made without taking into account the fact that the water body (the Ivanov Klyuch creek) is located within the boundaries of the section, thus belonging to the federal property, which is an integral part of the Malaya Ksha River, the transaction was declared invalid (null), as not corresponding to Art. 9 of the Land Code of the Russian Federation and Art. Art. 8 and 24 of the Water Act of the Russian Federation.

The applicant's arguments on referring a disputed land plot to agricultural land have no legal significance, since the existance of a record in the State Real Estate cadastre about the category of a disputed land plot can not change the type of water bodies located on it as well as the legal norms applied to such an object.

As can be seen from the case materials, there was an illegal sale of a land plot with a creek and a pond. Due to the small size and lack of definition on the following concepts: "creek", "pond", "stream pond" in the VC RF, the RF LC and other federal laws of Russia, illegal actions take place with such watercourses and reservoirs, including arbitrary damming and illegal transactions. In particular, they can be corruption acts. In turn, law enforcement agencies and the public are hampered in their actions, due to the fact that they have no direct relience on the norms of the federal legislation. Similar situations are described by foreign researchers in the relevant part [7].

Herewith, there are often incorrect statements in the arbitrage practice materials, such as: "the pond is not channel, but artificial". Providing to the statements of that kind, it is difficult to agree with the scientific point of view. According to paragraphs 178 and 179 GOST 19179-73 (have no binding force), ponds are always artificial. They are formed from the installation of a water-pressure structure on a watercourse (a river or a creek) for the purpose of preserving and regulating the flow or (and) in a specially excavated pit. However, these facts generally do not influence the validity of the court decision.

The prevailing tendency of arbitrage practice raises the urgent issue of the direct exclusion (prohibition) of ownership of stream ponds by individuals and legal entities, as in Article 8 of the VK RF.

Based on our arbitrage practice, a greater completeness of the norms and definitions of the water legislation is needed. Direct definitions of the following concepts "a river", "creek", "a lake", "a reservoir", "a pond", "a stream pond", "a watered quarry" are required in the VC RF. This idea was repeatedly substantiated, put forward and developed by specialists of the Institute of Legislation and Comparative Law under the Government of the Russian Federation [8].

So, in order to clearly define the range of water bodies for which private property is allowed, a legal definition of the concepts of ponds and flooded quarries is needed. This will ensure unambiguous interpretation of the provisions of the law, "reduce corruption risks due to the desire to privatize small lakes, calling them ponds; will avoid abuse and error on the part of state authorities and local self-government bodies "[4].

It should be noted that continuous supervision (monitoring), sequential cadastral registration of small waterways and water bodies will ensure the application of the law requirements to water use, as well as full-fledged water control and supervision. Unfortunately, over the course of a number of years many creeks and small rivers, ponds and watered quarries, as well as small lakes have become objects of arbitrary actions for damming, covering, and draining by economic entities. In many respects this became possible due to the incompleteness of the State Water Register and other state data banks, which literally excluded small water bodies and waterways from the legal field and often relieved the responsibility of the authorized authorities for these "formally not existing" surface water bodies.

All this is confirmed in the practical case that is described in the domestic media. For 
example, in a number of regions, high-ranking officials (officials and business leaders) initiate arbitrary damming up rivers for the purpose of saizing some picturesque groves and oak forests for building palaces. What is more, in the river bed or the lodge of lakes documents those land plots are shown as land suitable for housing, construction, and recreational purposes. The use of drainage zones of treatment facilities and dams by a narrow group of people for their entertainment purposes poses a threat to aquatic ecosystems. Once the channel feeding the lake was tightly covered for the sake of the cottage community under construction. The lake was used as a hunting and fishing ground by residents of the elite cottage community. Imagine their surprise when this reservoir became shallow completely just in a few years! Local authorities often turn a blind eye on such violations, and this requires identification of the corruption component. It is necessary to attract all stakeholders, environmental organizations, public chambers and councils in order to solve this problem.

Underground water objects and corruption risks

Protected by layers of rock formations, groundwater bodies in general are much less affected by negative impacts than surface rivers and lakes. However, unlike surface water bodies, groundwater does not possess sufficient mechanisms for self-purification due to its hydrological properties and it can contain harmful substances for about a century after the pollution itself happened.

In recent years, the growth of pollution and the depletion of groundwater has been clearly traced. Even in conditions of long-term legal regulation in the field of groundwater use, it is revealed that some plants has been pumping contaminated sewage into deep underground horizons. The Prosecutor's Office and Rostekhnadzor through the court pressed for the termination of pumping chemically contaminated substances containing the first hazard class waste (Mercury) [9]. The complexity and high latency of proving the causal relationship between the obvious consequences of the offense and the fact of the offense stay currently among the reasons for the ineffectiveness of legal liability measures related to offenses in the use and protection of groundwater. [10]

The variety of natural properties of groundwater determines the multi-purpose nature of their use, which determines the existence of multiple subjects possessing rights to use underground waters. The interests of above mentioned subjects may not coincide, and sometimes contradict each other, which can create abuses, conflict situations, litigation, etc.

The unambiguous clarity of the boundaries for any natural wealth in someone's property, lease, other ownership or use always serves as an important prevention against conflicts and abuses, including corruption activities [11]. This statement is valid for the horizons and basins of groundwater.

According to Article 5 of the RF CC, the boundaries for underground water bodies (aquifers and groundwater basins) are determined in accordance with the subsoil legislation. However, the Law "On Subsoil" is silent on such borders. As a result, Federal legislation does not at all contain a conceptual understanding of the boundaries for underground water bodies, including karst water bodies. In particular, it remains unclear what should be attributed to rocks that surround (or contain) natural waters, how to draw a border with neighboring geometrized subsoil plots legally provided to economic entities [3].

This task is especially important in view of further phased development of groundwater resources and attracting investments in this area. Unfortunately, including and due to the corruption component, some officials and some companies may "not notice" the use of suitable for drinking groundwater resources by oil and gas companies.

At the same time, the portion of groundwater in household and drinking water supply is more than $50 \%$ in the countries of the European continent. Objective causes (growing pollution of surface water) will soon lead Russia to the same state of affairs. There is a high risk that Russia will confront the sitiation when underground sources of water supply have 
already been polluted. The culprits of this impasse will be business entities and officials who have become involved in corruption relations [12].

Further, in connection with the activation of the development of groundwater resources, it is necessary to guarantee the interests of investors who create an expensive infrastructure, as well as to protect and promote public interests in sustainable water use. It is useful to promote contractual designs that ensure effective public-private partnership in the creation and functioning of artificial reservoirs with underground waters suitable for use in various sectors of the economy. In relation to these considerations, it would be practical to develop Approximate forms of the contract for the creation and functioning of artificial reservoirs with groundwater in subsoil, similar to the 'approximate forms' of water use agreements currently in force in connection with surface water bodies.

This proposal has an anti-corruption focus. After all, the licensing (licensing) procedure for granting subsoil for the construction of groundwater tanks proposed in a number of draft laws does not guarantee investment from arbitrary actions and, therefore, is not profitable for investors. If the authorities are able to revoke the license, then under the influence of unfavorable factors there will be a risk of arbitrary pressure and extortion from the responsible officials of these bodies in relation to economic entities. In turn, the contractual procedure for the use of groundwater presupposes an early termination of the right to use underground water bodies through the court. This legal property of the contractual order makes it difficult for corruption activities to continue.

Measures to eliminate the aforementioned consequences of groundwater pollution are provided for in Resolution No. 94 of the Government of the Russian Federation of February 11, 2016 "On Approving the Rules for the Protection of Underground Water Objects," which include the elimination of foci of groundwater pollution. Obviously, this measure should be carried out by economic entities entitled to use this natural resource and the ones to blame for the pollution that has occured. In any case, users of natural resources, if they exist, should not shy away from solving similar problems.

Foreign scientists also studied the problems of defects in legal regulation and management of groundwater use and protection of [13], [14].

The initiative on the All-Russian certification (inventory) of all drinking groundwater production facilities, including boreholes, wells and springs, is designed to regulate issues that have been missed in practice, which will reduce social tension, including corruption factors.

In case of observance of the requirements established by the law, the owners of land plots, land users, landowners, lessees of land plots have the right to use, within the boundaries of these land plots, groundwater for their own needs that is not on the state balance sheet, the extraction volume of which should not exceed 100 cubic meters in day (Part 1, Article 19 of the RF Law "On Subsoil"). At the same time, development of these subsoil assests is carried out without any approval in project documentation, which does not comply with the requirements of the law (Article 23.2 of the RF Law "On Subsoil"). The absence of project documentation, which can be identified at the time of verification, creates the ground for informal relations between economic entities with low legal awareness and dishonest officials prone to corruption acts.

In view of the above, it should be considered and consolidated in the legislation that organizations drilling single water wells, are obliged not to exceed the extraction volume of 100 cubic meters per day. Data on locations of wells, the date of installation, the depth, the approximate debit of the well should be also introduced in the funds of geological information.

The legal aspects of protecting groundwater resources are not simple in any country. Many people, interests and sectors of the economy are involved [15], [16]. It should be recognized and confirmed that law-making in the area of groundwater is carried out by 
federal and regional authorities (USA) [17]. An important factor in ensuring the most flexible legal regulation (which will consolidate measures to reduce corruption) in the use and protection of groundwater is the accounting of hydrogeological conditions and processes [18]. The reader is provided with the research of the Institute of Legislation and Comparative Law under the Government of the Russian Federation from a legal point of thought. [19].

Monopoly and corruption risks in the field of water relations

It is well known that the problem of fighting corruption is closely linked with the legal regulation of competition and economic concentration. Meanwhile, competition between users of natural resources (including water users) makes it possible to eventually rich the most environmentally justified conditions for the use of a particular type of natural resource with the least anthropogenic load.

In Art. 40 of the RF CC, a ban on monopolistic activities and unfair competition in the use of water bodies is enshrined. The federal executive authorities, state authorities of the subjects of the Russian Federation, local self-government bodies are prohibited from accepting acts and / or carrying out actions (inaction), as well as conclude agreements or carry out concerted actions in the use of water bodies that lead or may lead to prevention, restriction, elimination of competition.

While maintaining a general ban on monopolistic activity and unfair competition in the studied area, there are gaps in the VC RF and subordinate regulatory legal acts that create risks of restricting competition and corruption activities.

Proceeding from art. $19 \mathrm{VK}$ RF, water user has the right to transfer his/ her rights and obligations to another person under the contract of water use with the consent of authorized state authorities or local self-government. The transfer of rights and obligations to another person under the contract of water use is carried out in accordance with the civil legislation (the legislator does not even specify which of the civil-legal mechanisms are being applied). Wherein, because the water use agreement is based on the VK RF on the basis of an auction, the transfer of rights to another person under this agreement facilitates circumvention by interested parties of the water legislation requirements on the clause that the "new" water user should win the auction [8], [20].

If a previous water user won an auction and concluded a water use contract based on its results, the new water user gets his rights and obligations under the water use agreement and takes the place of his predecessor bypassing any trades.

This inevitably leads to a restriction of competition and corruption practicies, which in turn can lead to the formation of "shadow" water users-monopolists that might supersede other economic entities that initially win tenders.

In st.19 VK RF some procedural issues of the studied relations are regulated; however, it does not eliminate corruption risks. A water user's application for giving consent for the transfer of rights and obligations to another person under a water use agreement must be considered by an executive body of the state authority or a local government no later than thirty days from the receipt of such a statement. In turn, the refusal of the executive body of the state authority or the local government to give consent for the transfer of rights and obligations to another person under a water use agreement may be appealed in a judicial procedure. Rights and obligations under the water use contract are considered transferred after registration in the state water register. Consequently, the authorized bodies are obliged to support such restriction of competition.

Thus, through the legal design of the transfer of rights and obligations under the contract of water use, it becomes possible to avoid punishment bending the competition rules regarding the admission of economic entities to water objects. Moreover, advantages are created for a number of persons, leading to restriction of competition.

In view of the foregoing, amendments and additions are required to the RF CC and by- 
laws which need to regulate the relationship between old and new water users the way that in the event of the transfer of rights and obligations under the water use agreement, the competitiveness in the area of access to water objects by economic entities will be preserved as well as the corruption risks neutralized.

\section{Discussion}

Possibilities of public control in Russia in connection with corruption risks and practicies

We have identified a lot of corruption risks and practicies in the use and protection of water bodies. To create a barrier of corruption, including in the area under study, it is necessary to use the potential of Russian legislation in the field of public control. First of all, it is necessary to consider the provisions of Federal Law No. 32-F3 of April 4, 2005 "On the Public Chamber of the Russian Federation" (hereinafter - the Law).

Cited social structure ensures the interaction of citizens of the Russian Federation, public associations, trade unions, creative unions, unions of employers and their associations, professional associations, as well as other non-profit organizations, with various bodies and levels of power in order to take into account needs and interests, protect rights and freedoms citizens of the Russian Federation during the formation and implementation of state policy for the purpose of exercising public control over the activities of federal bodies of executive power, executive authorities of the subjects of the Russian Federation and local self-government bodies. The requests and conclusions of the Public Chamber can not remain without any attention of state authorities and local selfgovernment; however, the decisions of the Public Chamber are recommendatory for them.

Given provisions of the Law unequivocally call for the protection of the rights of citizens in terms of environmental management and environmental protection, as enshrined in the Constitution of the Russian Federation and the legislation of our country through a number of forms of public control. The powers of the Public Chamber of Russia can be applied to identify, suppress and eliminate the consequences of corruption activities in the natural resource sphere.

The mechanism for the protection of the rights of citizens in the field of environmental management and environmental protection is also laid down in Federal Law No. 212-FZ of 21 July 2014 "On the Basics of Public Control in the Russian Federation". According to Art. 9 of this Federal Law, subjects of public control are: the Public Chamber of the Russian Federation, public chambers of the subjects of the Russian Federation, public chambers (councils) of municipal entities, public councils under federal executive bodies, public councils of legislative (representative) and executive bodies of state power of subjects Russian Federation.

Various organizational structures of public control can be established, such as, public monitoring commissions, public inspections, public control groups for the implementation of public control in cases and in the manner prescribed by the legislation of the Russian Federation.

Public control is carried out in the forms of public monitoring, public inspection, public examination, as well as in the following forms of cooperation: public discussions, public (public) hearings and other forms of engagement. Given forms of public control help to identify and neutralize corruption-related factors in the natural resource area.

\section{Conclusion}


It is generally accepted that neutralization of corruption activities in the sphere of the use of natural resources, including water resources, plays an important role in ensuring the environmental safety of the state.

In the field of use and protection of water objects in Russia, corruption increases environmental threats and undermines the legal regulation of relations on the use and protection of the water fund. Corruption in this area often goes beyond the routine relations of citizens and officials (domestic corruption) and concerns relations in the field of carrying out entrepreneurial activities (business corruption). It is often feeds on the existing negative phenomena of monopolism and legal nihilism. In order to fight corruption in this area, it is necessary not only to strictly enforce the law requirements, but also to develop further water and related legislation, excluding corruption risks and activities.

The changes proposed by the authors in the laws and subordinate regulatory legal acts, as well as in a number of enforcement practice segments, will make it possible to fill the gaps and remove contradictions in the legal regulation of water relations. At the same time, it is precisely in the neutralization of corruption-related factors in the field of water relations that the necessary prerequisite for ensuring sustainable water use is concluded. If the proposals given by the authors are implemented, the effectiveness of the legal regulation of water and other environmental resources will be enhanced.

It appears that the authors' proposals will contribute to further differentiation of the legal regulation of relations in the field of the water fund use and protection. These proposals will enchance the emergence of new legal institutions and sub-institutions, as well as the development of specific methods and methods of influencing the participants of the relations studied [21].

\section{References}

1.Protivodejstvie korrupcii: novye vyzovy. Monografiya. Pod. Red. T.YA. Habrievoj. M.: IZiSP. Infra-M. 2016.-376 p.;

2.Kommentarij k Vodnomu kodeksu Rossijskoj Federacii (postatejnyj) / S.A. Bogolyubov, G.A. Volkov, D.O. Sivakov / Otv. red. S.A. Bogolyubov. - M.: Velbi, Izd.-vo Prospekt, 2007. - 248 p.;

3. Bogolyubov S.A. i dr. Realizaciya prav sobstvennosti na prirodnye resursy. IZiSP. M. YUrist. 2007. - $192 \mathrm{p}$.

4. Vodnoe zakonodatel'stvo i ehkologicheskie vyzovy. Sb. mat. Nauchno-prakticheskoj konferencii. M. 15 iyunya 2012. / Sost. S.A. Bogolyubov. D.O. Sivakov. O.A. Zolotova. M. IZiSP. Izd-vo «Ankil». 2012g. pp.305-309;

5. Miheev N.N. Voda - ne tovar // EHkologiya i zhizn'. 2005. №7 (48), pp. 22- 23;

6. Sivakov D.O. Vodnoe pravo Rossii i zarubezhnyh gosudarstv. - M.: YUsticinform, 2010. $-368 \mathrm{p}$.

7. Narong Jaiharn and Naporn Popattanachai An Analysis of Thai Water Management Legislation from an International Law Perspective // Yonsei Law Journal Vol. 4 No. 2, November 2013, pp.351-369.

8. Nauchnye koncepcii razvitiya rossijskogo zakonodatel'stva: monografiya. 7-e izd. dop. i pererab. Otv. red. T.YA. Habrieva, YU.A. Tihomirov. IZiSP. M. YUrisprudenciya. 2015, pp.302-315;

9. Plata za gryaz' // Ehkologiya i zhizn'. 2007. №10. pp.20-21;

10. Muhina EH.N. Pravovoe regulirovanie ispol'zovaniya i ohrany podzemnyh vod. Avtoreferat na soiskanie uchenoj stepeni kandidata yuridicheskih nauk. Special'nost' 
12.00.06. - prirodoresursnoe pravo; agrarnoe pravo; ehkologicheskoe pravo. M. 2011. pp.11-12;

11. Kolbasov O.S. O novom Vodnom kodekse Rossijskoj Federacii // Zakonodatel'stvo i ehkonomika. 1997. № 1-2. p. 15.

12. Mechlem K. International Groundwater Law: towards closing the gaps // Yearbook of International Environ mental Law. 2003. Vol.14.

13. Nicholaus E. Johnson Finding the Leaks in the Sustainable Groundwater Management Act // The University of the Pacific Law Review / Vol.47, Issue 4. 2016, pp.641-663.

14. Richard M. Frank, California Groundwater Law: An Overview (2014).

15. Broslavskij L.I. Ehkologiya i ohrana okruzhayushchej sredy: zakony i realii SSHA i Rossii. Monografiya. M. Infra-M. 2013. pp. 156-175, 259-260.

16. Zharikov Yu.G., Masevich M.G. Nedvizhimoe imushchestvo: pravovoe regulirovanie: nauchno-prakticheskoe posobie. IZiSP. M.BEK. 1997. 256 p.

17. Fajerstoun D.B., Rid F.S. Vvedenie v ehkologicheskoe pravo (per. s angl. A.L. Reznikova) Petrozavodsk. 2002. pp.81-83.

18. Lange O.K. Osnovy gidrogeologii. Izd-vo MGU.1950.-232 p.

19. Instituty ehkologicheskogo prava/ S.A. Bogolyubov i dr. M.Ehksmo. 2010. pp.300-305.

20. Sivakov D.O. Tezisy o vodnom prave Rossii // Agarnoe i zemel'noe pravo. 2017. № 1, pp. 65-71.

21. Sivakov D.O. Differenciaciya pravovogo rezhima ispol'zovaniya i ohrany vodnogo fonda kak neobhodimoe uslovie razvitiya vodnogo hozyajstva // V mire nauchnyh otkrytij. Krasnoyarsk. Nauchno-innovacionnyj centr, 2015. № 2.1, pp.711-720. 